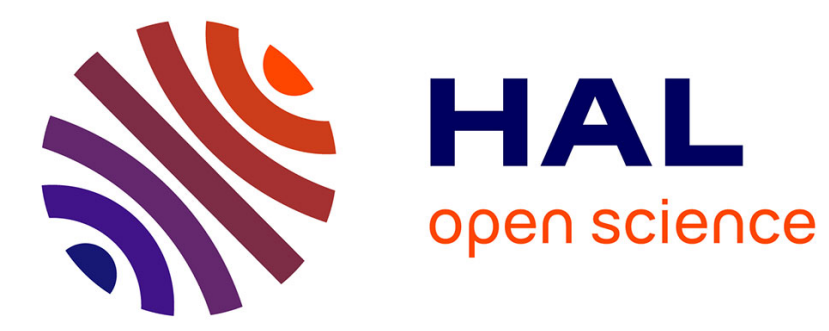

\title{
Impact of Erysiphe alphitoides on transpiration and photosynthesis in Quercus robur leaves
}

\author{
Mostafa Hajji, Erwin E. Dreyer, Benoit Marçais
}

\section{To cite this version:}

Mostafa Hajji, Erwin E. Dreyer, Benoit Marçais. Impact of Erysiphe alphitoides on transpiration and photosynthesis in Quercus robur leaves. European Journal of Plant Pathology, 2009, 125 (1), pp.63-72. 10.1007/s10658-009-9458-7 . hal-02103659

\section{HAL Id: hal-02103659 \\ https://hal.science/hal-02103659}

Submitted on 18 Apr 2019

HAL is a multi-disciplinary open access archive for the deposit and dissemination of scientific research documents, whether they are published or not. The documents may come from teaching and research institutions in France or abroad, or from public or private research centers.
L'archive ouverte pluridisciplinaire HAL, est destinée au dépôt et à la diffusion de documents scientifiques de niveau recherche, publiés ou non, émanant des établissements d'enseignement et de recherche français ou étrangers, des laboratoires publics ou privés. 


\title{
Impact of Erysiphe alphitoides on transpiration and photosynthesis in Quercus robur leaves
}

\author{
Mostafa Hajji ${ }^{1}$, Erwin Dreyer ${ }^{2}$ and Benoit Marçais ${ }^{1}$ \\ 1 INRA, Nancy Université, UMR1136 Interactions arbres-microorganismes, INRA-Nancy, \\ 54240 Champenoux \\ 2 INRA, Nancy Université, UMR1137, Ecologie et Ecophysiologie forestières, INRA-Nancy, \\ 54240 Champenoux (dreyer@nancy.inra.fr)
}

Corresponding author: B. Marçais, Tel: (33)3 833940 53, Fax: (33)3 83394069 marcais@nancy.inra.fr

\section{Abstract}

Oak powdery mildew, (Erysiphe alphitoides) causes one of the most common diseases of oaks. We assessed the impact of this pathogen on photosynthesis and water relations of infected leaves using greenhouse grown oak seedlings. Transpiration of seedling infected by oak powdery mildew was also investigated.

Altogether, E. alphitoides had a low impact on host gas exchange whether at leaf or whole plant scale. Maximal stomatal conductance of infected leaves was reduced by $20-30 \%$ as compared to healthy controls. Severely infected seedlings did not experience any detectable change of whole plant transpiration.

The reduction in net $\mathrm{CO}_{2}$ assimilation, $\mathrm{A}_{\mathrm{n}}$, was less than proportional to the fraction infected leaf area. Powdery mildew reduced both the maximal light driven electron flux $\left(\mathrm{J}_{\max }\right)$ and the apparent maximal carboxylation velocity $\left(\mathrm{Vc}_{\max }\right)$ although $\mathrm{Vc}_{\max }$ was slightly more impacted than $\mathrm{J}_{\max }$. No compensation of the infection occurred in healthy leaves of partly infected seedlings as the reduced photosynthesis in the infected leaves was not paralleled by increased $A_{n}$ levels in the healthy leaves of the seedlings. However, E. alphitoides had a strong impact on leaf life-span of infected leaves.

It is concluded that the moderate effect of $E$. alphitoides on oak might be related to the small impact on net $\mathrm{CO}_{2}$ assimilation rates and on tree transpiration; nevertheless, the severe reduction in leaf life-span of heavily infected leaves may lead to decreased carbon uptake over the growth season.

Key word: powdery mildew, pathogen $\mathrm{CO}_{2}$ assimilation, gas exchange

\section{Introduction}

Oak powdery mildew caused by Erisyphe alphitoides (Griffon \& Maubl.) U. Braun \& S. Takam. (formely Microsphaera alphitoides) is one of the most common diseases of pedunculate (Quercus robur L.) and sessile (Q. petraea Matt. Liebl.) oaks in Europe. Q. robur is the most susceptible species. E. alphitoides is an exotic pathogen that began spreading in Europe during 1907 (Foex, 1941). The disease can be very severe, especially in young regenerations. In young stands, it reduces growth and causes a large seedling mortality 
(Soutrenon, 1998). In mature trees, the disease is generally considered as far less damaging although it can reduce tree vigour in conjunction with other factors such as defoliation by insects, and therefore contribute to tree decline (Thomas et al., 2002, Marçais and Breda, 2006). Only young developing leaves are susceptible to infection by $E$. alphitoides (Edwards and Ayres, 1982). Colonisation by the pathogen induces tissue necrosis only when infection occurs very early during leaf development. As the pathogen develops quite late in spring, after the growth of the first flush of oak saplings, the disease is especially prevalent on the second and third flushes that develop between end of June and August. This mitigates the severity of the disease on large trees. However, the French forest-health survey network recently mentioned severe infection on mature oak trees and suggested that the pathogen could in some cases trigger tree decline. This appears to be linked with an arrival of the pathogen early in the vegetation season. There was therefore a need to analyse the consequences of severe attacks for tree physiology and in particular for its water use and its ability to assimilate carbon through photosynthesis.

It is well known that foliar pathogens reduce net $\mathrm{CO}_{2}$ assimilation by leaves (Lakso et al., 1982; Ellis et al., 1981; Shtienberg, 1992; Sabri et al., 1997). This is due to a direct action on photosynthetic processes or to a reduction of stomatal conductance or to both. Indeed, many leaf pathogens induce stomatal closure (Mignucci and Boyer, 1979; Niederleitner and Knoppik, 1997; Pinkard et al., 2006), although there might be some exceptions (Lakso et al., 1982). A direct effect of the leaf pathogen on photosynthetic processes could be a reduction of carboxylation efficiency due to a possible impact on RUBISCO or on other enzymes of the Calvin cycle (Pennypacker et al.; 1990; Niederleitner and Knoppik, 1997 ; Mayr et al., 2001). Leaf pathogens can also alter light interception and photochemistry due to chlorophyll decay and consequently limitation in light driven electron fluxes (Holloway et al., 1992; Niederleitner and Knoppik, 1997; Manter, 2002; Bassanezi et al., 2002).

We know that $E$. alphitoides does reduce carbon assimilation in leaves $\left(A_{n}\right)$ and translocation of carbohydrates from infected leaves to the rest of the plant (Hewitt and Ayres, 1975; Hewitt and Ayres, 1976). However, to properly assess the impact of oak powdery mildew on whole tree physiology, we need to know the relationship between severity of leaf infection and physiological dysfunction such as reduction of $A_{n}$ or altered transpiration, which has not yet been studied. Fraction of infected leaf area is usually not an efficient estimate of the magnitude of a pathogen impact on leaf $\mathrm{CO}_{2}$ assimilation (Shtienberg, 1992; Bassanezi et al., 2002; Robert et al., 2005). Bastiaans (1991) introduced the concept of virtual lesions to assess the impact of a pathogen on leaf physiology. A larger impact than expected from lesion size could be caused by a toxin or by an accumulation of carbohydrates within the infected leaves due to altered translocation (Wright et al., 1995). In contrast, increased photosynthesis in the healthy areas of infected leaves, caused by altered sink-source relationship, could explain the occurrence of a smaller than expected impact of lesion size. Such a compensation of infection by the healthy parts of the seedlings could also occur at whole plant level, with increased photosynthesis in healthy leaves. This was described on spruce trees infected by rust (Mayr et al., 2001).

Foliar pathogens often alter leaf stomatal conductance (Niederleitner and Knoppik, 1997; Pinkard and Mohammed, 2006). E. alphitoides increased transpiration of infected oak leaves (Hewitt and Ayres, 1975). However, little is known about the impact of foliar pathogens on whole plant water use. Such an impact on transpiration could be very detrimental owing to the frequency of $E$. alphitoides and to the fact that water shortage during drought is one of the main causes of oak decline.

We thus tested following hypotheses to document the physiological impact of controlled levels of infection with E. alphitoides, on leaves of Quercus robur seedlings:

1. Reductions in net $\mathrm{CO}_{2}$ assimilation rates $\left(\mathrm{A}_{n}\right)$ are proportional to the fraction infected area of the leaves;

2. Heavy infection results in a compensating increase of $A_{n}$ in the non infected leaves; 
3. Heavy infection leads to altered transpiration at leaf and whole sapling level.

These questions were addressed with seedlings that were manually infected with suspensions of spores of the fungus.

\section{Material and Methods}

\section{Plant material}

The experiments were conducted with one -year-old Quercus robur seedlings grown from acorns (15-25 cm high) collected in the Amance forest (close to Nancy, Meurthe-etMoselle, NE France) except otherwise stated. Plants were grown in an outdoor nursery, planted into in $5 \mathrm{I}$ pots $(1 / 1, \mathrm{v} / \mathrm{v}$ sand-peat potting mix) and transferred during the winter preceding the experiment to a greenhouse. Nutrients were supplied at planting under the

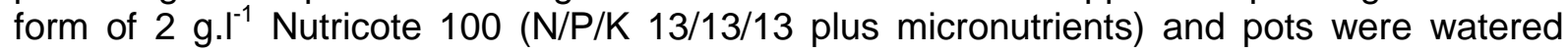
daily.

\section{Inoculation and infection rating}

Inoculation was performed by applying $E$. alphitoides spores with a thin paintbrush onto the upper face of expanding leaves when they had reached about $70-90 \%$ of their final area. The spores were produced on infected oak seedlings that were shaked one day before the experiment to avoid presence of old spores. The oak powdery mildew used for inoculation was a population from the Amance forest (Meurthe-et-Moselle, NE France) maintained on $Q$. robur seedling in greenhouse. Depending on the experiment, we either tried to produce homegeneously infected oak seedlings, with different levels of infection (see below) or seedlings with leaves at different levels of infection. For this purpose, we applied the following dry-inoculation treatments:

i. no inoculation and protection for 5 days of the leaves with cellophan bags allowing gas exchange, in order to prevent cross-infections;

ii. one spot toward the center of the leaf with a very thin brush (no 4);

iii. $\quad 3-4$ spots scattered on the leaf with a medium brush (no 8);

iv. inoculation of the entire leaf surface with the medium brush.

We designed the inoculation procedure as to obtain leaves with each of the 4 treatments on the same branch. Non-inoculated seedlings protected from infection with cellophane bags and placed in the same conditions than inoculated ones were used as controls.

Two to 3 weeks after inoculation, leaves were rated for infection on a $0-4$ scale: 0 , no infection; 1 , one to three lesions of mildew and less than $25 \%$ of leaf area infected; 2 , more than 3 lesions or $25-50 \%$ of the leaf surface infected; 3, more than $50 \%$ of leaf surface infected; 4, leaf with necrosis and/or abnormal growth with infection related deformation. At that time, lesions were sporulating. Studied leaves were selected a posteriori to represent infection classes 0 to 3 . Leaves in class 4 were not included in the study because the major impact of $E$. alphitoides on those leaves was to drastically reduce their functional area, and to lead to the formation of small and distorted leaves. To assess the fraction of infected leaf area, contours of the leaves and of the infected areas were recorded at the end of each experiment on a plastic sheet and the total leaf and infected area were computed with a video leaf-area meter DeltaT (DeltaT, Hoddesdon, UK).

Experiment 1: transpiration of whole plants. Sixty 2-year-old oak seedlings were randomly assigned to 4 inoculation treatments: i, non inoculated controls; ii, 2 spore spots on each leaf with a thin brush (no 4); iii, 4 spore spots on each leaf with a medium brush (no 8); iv, inoculation of the entire surface of all leaves with the medium brush. Plants were rated for infection 4 weeks after inoculation, with each leaf rated according to the above description. 
The seedling infection rating was computed as the mean of all leaf ratings. Fourty one seedlings with infection rating from 0 to 3.5 were then selected for the study.

The potted seedlings were transferred to a climate chamber at a temperature of $25^{\circ} \mathrm{C}$ with a $17 \mathrm{~h}$ photoperiod and with an irradiance in the PAR of $200 \mu \mathrm{mol} \cdot \mathrm{m}^{-2} \cdot \mathrm{s}^{-1}$. A fully randomized experimental design was used. Each pot was weighed twice a day, in the morning and at the end of the afternoon, during 5 days in a row. Irrigation was provided daily in the evening after weighing the pots. The fifth day, leaves were sampled, dried for $48 \mathrm{~h}$ at $60^{\circ} \mathrm{C}$ and then weighted. Leaf area was measured on a sample of 10 leaves per seedling in order to compute specific leaf area, i.e., area per unit dry weight (SLA). Total leaf area of each seedling was computed as the product of total leaf dry weight and SLA.

Experiment 2: stomatal conductance and leaf transpiration in situ. Stomatal conductance and transpiration were measured on leaves from the 4 milder infection classes (0 to 3) on 12 one to two-year-old Quercus robur with a null balance porometer LiCor 1600 (LiCor, Lincoln, Nebraska). About 2-8 leaves were measured on each seedling (sample size of $20,6,13$ and 11 respectively for rating of 0,12 and 3 ). Whenever possible, a representative leaf of each infection class was measured on each seedling. The measurements were made outdoors during a sunny summer afternoon (13h30-14h30), and transpiration and stomatal conductance were recorded on both sides of the leaves to test whether infection induced water losses from the adaxial surface ( $Q$ robur is hypostomatal).

Experiment 3: photosynthesis of infected leaves. The photosynthesis of mildewinfected leaves was measured under laboratory conditions with a portable photosynthesis chamber LiCor 6400 (LiCor, Lincoln, Nebraska), on leaves that had been infected 3-4 weeks earlier. Ten infected and 8 healthy seedlings were measured. For infected seedlings, 1-2 leaves of each of the 4 milder infection classes ( 0 to 3 ) were measured while only one leave was measured on healthy seedlings. Healthy and infected seedlings were measured alternatively. All toghether, 53 leaves were measured $(13,9,11$ and 12 leaves respectively for rating of 0,12 and 3 on diseased seedlings and 8 leaves on healthy seedlings).

The $6 \mathrm{~cm}^{2}$ leaf chamber was clamped randomly to the leaf, not taking into account mildew infection. Leaf temperature was controlled at $24^{\circ} \mathrm{C}$, relative humidity maintained between $60 \%$ and $70 \%$, and incident photosynthetic photon flux density set at $1000 \mu \mathrm{mol} . \mathrm{m}^{-}$ ${ }^{2} . \mathrm{s}^{-1}$. The sequence started by $20 \mathrm{~min}$ at a $\mathrm{CO}_{2}$ concentration of $400 \mu \mathrm{mol}^{-\mathrm{mol}^{-1}}$ to fully activate photosynthesis, followed by $3 \mathrm{~min}$ periods at each of the following $\mathrm{CO}_{2}$ concentrations (in the order, 300, 250, 200, 150, 100, 50, 600, 900, 1200, 1500 and $\left.1800 \mu \mathrm{mol} . \mathrm{mol}^{-1}\right)$. Three measurements at $20 \mathrm{~s}$ intervals were made at the end of each 3 min. period. After the step at $1800 \mu \mathrm{mol}^{\mathrm{mol}}{ }^{-1} \mathrm{CO}_{2}$, the leaf was left in the dark at $400 \mu \mathrm{mol} . \mathrm{mol}^{-1} \mathrm{CO}_{2}$ for $25 \mathrm{mn}$ to measure leaf respiration.

Net $\mathrm{CO}_{2}$ assimilation rate, $\mathrm{A}$, was assumed to be related to $\mathrm{C}_{\mathrm{i}}$, the intercellular $\mathrm{CO}_{2}$ concentration within the leaf by the following minimum relationship (Farquhar et al., 1989):

$\mathbf{A}=(1-0.5 / \tau . \mathrm{Ci}) \times \min \left\{\mathbf{W}_{\mathbf{j}}, \mathbf{W}_{\mathbf{c}}\right\}$

With:

$$
\begin{aligned}
& \mathbf{W}_{\mathbf{c}}=\frac{\mathrm{C}_{\mathrm{i}}}{\mathrm{C}_{\mathrm{i}}+\mathrm{K}_{\mathrm{c}}\left(1+\mathrm{O} / \mathrm{K}_{\mathrm{o}}\right)} \times \mathbf{V}_{\text {max }} \\
& \mathbf{W}_{\mathbf{j}}=\frac{\mathrm{C}_{\mathrm{i}}}{4 \times\left(\mathrm{C}_{\mathrm{i}}+\mathrm{O} / \tau\right)} \times(\alpha \times \mathrm{Q}) \times \sqrt{\frac{1}{1+\left(\left(\alpha^{2} \times \mathrm{Q}^{2}\right) / \mathbf{J}_{\text {max }^{2}}\right)}}
\end{aligned}
$$

and $\mathrm{O}, \tau, \alpha, \mathrm{Q}, \mathrm{K}_{\mathrm{c}}$ and $\mathrm{K}_{\mathrm{o}}$ being either known constants or parameter with a known value at a given temperature (Dreyer et al., 2001). The fitting of the relationship was done using the procedure NLIN of SAS and enabled us to estimate $\mathrm{V}_{\mathrm{c}_{\max }}$ et $\mathrm{J}_{\max }$. As we used intercellular $\mathrm{CO} 2$ concentration as a basis for the computation, and not the chloroplastic one, 
and as it is known that internal resistance to $\mathrm{CO} 2$ transfer in oaks is not negligible, these estimates have to be considered as apparent values integrating a transfer component; real $V_{c_{\max }}$ (and to a lesser extent real $J_{\max }$ ) are probably larger (Ethier and Livingston, 2004).

At the end of each experiment, leaves were sampled and their total area as well as the fraction area infected by mildew were assessed as stated above. Leaves were then dried at $60^{\circ} \mathrm{C}$ for $48 \mathrm{~h}$ and ground (with a ball-mill during $1,5 \mathrm{mn}$ ) after determination of their dry weight. Carbon and nitrogen concentrations were measured with an elemental analyser (Thermo Quest NA 1500 NCS, Carlo Erba, Italy) from 2-3 mg of powder for each sample.

Experiment 4. Shedding of $E$. alphitoides infected leaves under natural conditions. In order to assess whether infection by oak powdery mildew decreased leaf lifespan, 100 Q. robur seedlings with leaves at different infection levels were sampled in a natural regeneration of the Amance Forest (Meurthe-et-Moselle, NE France). Seedlings were growing below the canopy of parent trees. Seedlings were sampled as to obtain an even distribution of leaves with similar infection levels all over the $10 \times 10 \mathrm{~m}$ plot. Two leaves of the second flush (formed beginning of July) were sampled per seedling. Altogether, 54 healthy leaves (infection rating of 0 ), 45 leaves rated 1, 50 leaves rated 2, 26 leaves rated 3 and 23 leaves rated 4 were sampled. The leaves were observed every 3-4 days from midjuly to mid-september to detect leaf decay and shedding. Leaf life-span was estimated through a survival analysis with the Kaplan-Meier non-parametric method, using the leaf infection index as an independent variable. The only censure occurring in the data was for leaves that had not been shed by mid-september. The model was fitted with the SAS procedure PHREG (SAS/STAT 8.1, SAS Institute Inc., Cary, NC).

\section{Statistical analyses}

The relationship between seedling transpiration and infection level was analysed with a mixed model using SAS. First order autoregressive covariance structure was assumed for transpiration during successive days.

Two different types of analyses were performed. First, we compared leaf characteristics ( $\mathrm{C}$ and $\mathrm{N}$ contents, stomatal conductance, respiration in the dark, $\mathrm{Vc}_{\max }$ and $J_{\max }$ ) of healthy leaves from either entirely healthy seedlings or partly infected ones, in order to detect possible compensation processes induced by infection. This was done with a Student t-test. Second, the same leaf traits were compared among the different leaf infection levels (rating 0 to 3 ). This was done by variance analysis taking the infection index as a fixed effect and the seedlings as a random factor, using the procedure "mixed" of SAS.

\section{Results}

The relationship between infection index and the fraction leaf area infected by E. alphitoides was as expected very tight. The mean fraction infected leaf area was respectively $15.7 \% \pm 2.4 \%, 32.7 \% \pm 2.9 \%$ and $69.0 \% \pm 16.7 \%$ for indexes 1,2 and 3 respectively (n respectively of 19,22 and 22 , confidence intervals given).

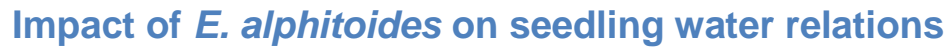

Despite the large range of infection levels reached on leaves of the tested seedlings, no significant relationship could be detected between transpiration of whole seedlings recorded during 5 days and the level of infection by oak powdery mildew (Fig. $1, F=1.99$, $p=0.166)$. A more specific analysis showed that daily transpiration was not related to infection level at any time $(F=0.97, p=0.3302)$ and that no time * infection index interaction could be detected $(F=0.42, p=0.7943)$.

No transpiration flux was detected with a null balance porometer during experiment 2 on the adaxial leaf surface whatever the infection level, despite the visible presence of powdery mildew on this side of the leaf. In contrast, a large transpiration flux was detected 
whatever the infection level on the abaxial face of the leaf. Infection had a significant impact on stomatal conductance, decreasing it by $15-30 \%$ for leaves with infection indexes of 1-3 compared to healthy leaves of the same seedling (Fig. 2, $F=10.99, p<0.001$ ).

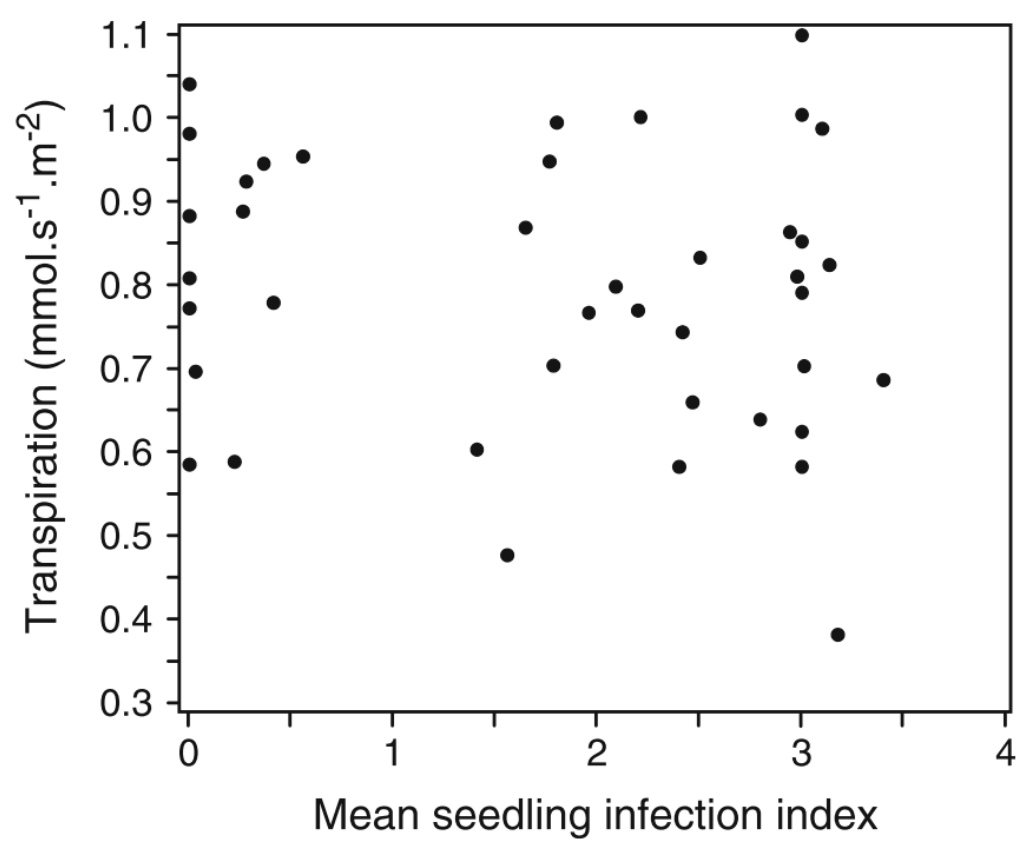

Fig. 1. Mean transpiration of whole $Q$. robur seedlings infected by oak mildew during a 5 day period in a climate chamber as a function of the mean seedling infection index (from 0: healthy to 3: fully covered with powdery mildew). Each point refers to a different seedling.

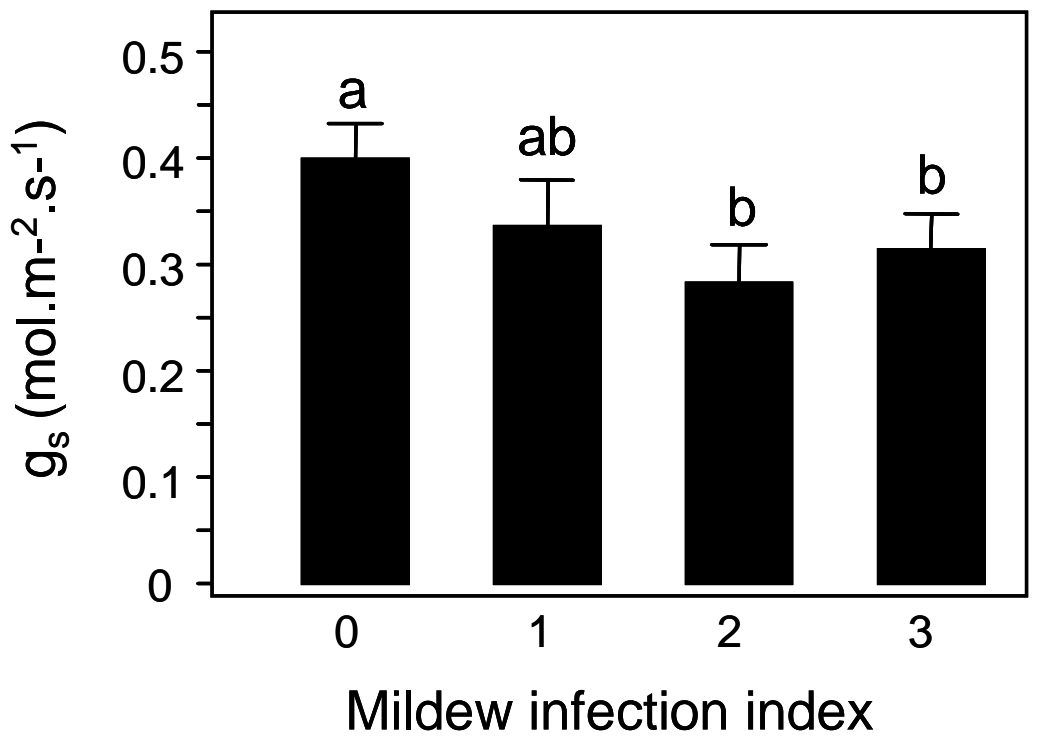

Fig. 2. Stomatal conductance $\left(g_{s}\right)$ measured with a porometer LiCor 1600 ) on the abaxial surface of $Q$. robur leaves infected by oak mildew as a function of infection index (from 0: healthy leaf to 3: leaves fully covered with powdery mldew). Bar represent confidence intervals. 


\section{Photosynthesis of leaves infected by $E_{\text {. alphitoides }}$}

Leaf mass to area ratio (LMA) did not differ between leaves with different infection levels within a seedling $(F=0.98, p=0.415)$. Similarly, no difference could be detected between healthy leaves of infected or healthy seedlings $(t=1.54, p=0.139)$. LMA values were in the range 30 to $35 \mathrm{~g} \cdot \mathrm{m}^{-2}$. The composition of leaves was altered by infection (Fig. 3): carbon content increased significantly with the level of infection $(F=4.23, p=0.012)$ while the nitrogen content decreased $(F=7.01, p=0.001)$. There was no difference in carbon content between healthy leaves of healthy seedlings compared to healthy leaves of partly infected seedlings $(t=1.42, p=0.172)$. In contrast, the difference was significant for nitrogen content as the healthy leaves of partly infected seedlings had a higher content than the healthy leaves of entirely healthy seedlings (Fig. $3 b, t=3.00, p=0.007$ ). During these measurements, a negative impact of $E$. alphitoides was again detected on stomatal conductance of infected leaves (Fig. 3c, $F=3.75, p=.0244$ ). Dark respiration was significantly increased (Fig. $3 d, F=7.60, p<0.001$ ). The mean decrease in stomatal conductance was 22,16 and $11 \%$ for leaves with infection levels of respectively 1,2 and 3 .
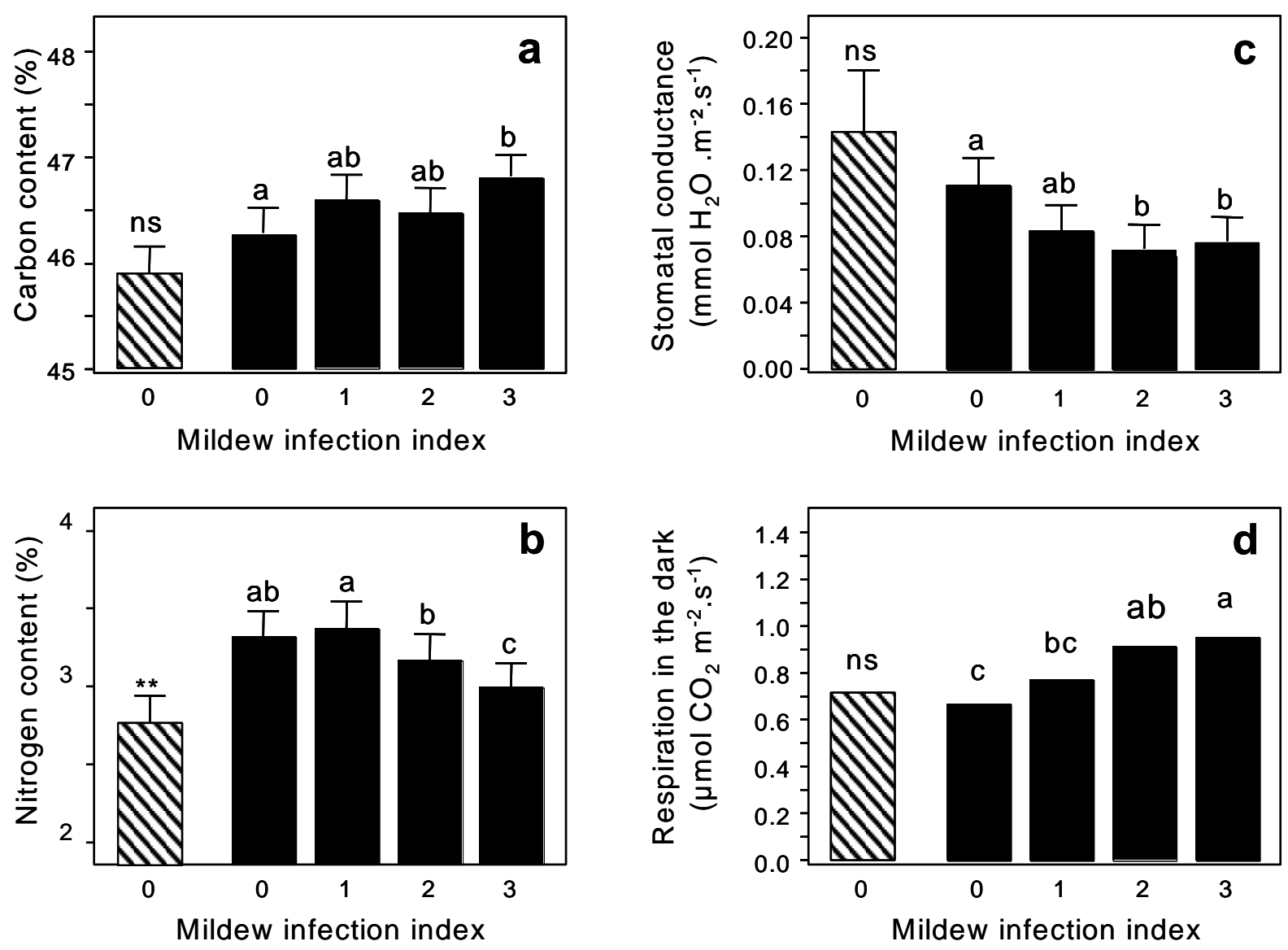

Fig. 3. Impact of oak mildew on composition and physiology of infected Q. robur leaves. a, Carbon content; b, Nitrogen content; c, Stomatal conductance; d, dark respiration. Stomatal conductance and dark respiration were measured with a portable photoqsynthesis chamber LiCor 6400 . leaves on healthy control seddlings. The sign above the bar indicates whether these leaves are significantly different from healthy leaves of partly infected seedlings. oak mildew. Infection index: 0, healthy leaf; 3: leaves fully covered with oak mildew. Bar represent confidence intervals. 
E. alphitoides reduced net $\mathrm{CO}_{2}$ assimilation of infected leaves. This was evidenced by a negative relationship between the fraction infected leaf area (propinf) and $A_{n}$, the net $\mathrm{CO}_{2}$ assimilation rate (Fig. $4, \log \left(A_{n}\right)=1.96-0.93 \times \%$ leaf_area_infected, $r^{2}=0.479, p<0.0001$ ). While healthy leaves displayed values of $7.5 \pm 1.2 \mu \mathrm{mol} . \mathrm{m}^{-2} \cdot \mathrm{s}^{-1}, \mathrm{~A}_{\mathrm{n}}$ was around $4.5 \mu \mathrm{mol} . \mathrm{m}^{-}$ ${ }^{2} . s^{-1}$ at $50 \%$ infected leaf area, i.e., a level of net $\mathrm{CO}_{2}$ assimilation still above $50 \%$ of the value observed in healthy leaves. The higher infection levels $(85-100 \%)$ corresponded to a decrease of $A_{n}$ by about $40-50 \%$. No difference was detected between healthy leaves of partially infected or entirely healthy seedlings for net $\mathrm{CO}_{2}$ assimilation rates (respectively $7.6 \pm 1.4$ and $\left.9.2 \pm 2.0 \mu \mathrm{mol} . \mathrm{m}^{-2} . \mathrm{s}^{-1}, \mathrm{t}=1.57, \mathrm{p}=0.133\right)$.

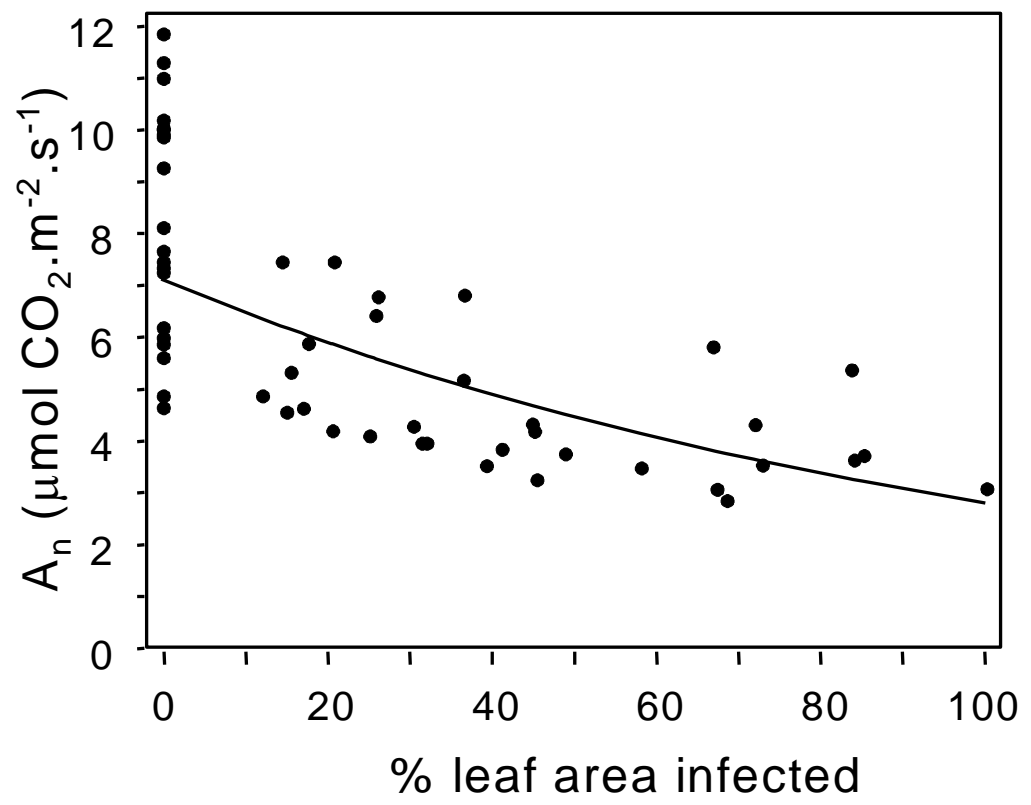

Fig. 4. Relationship between leaf infection by oak mildew and $A_{n}$, net $\mathrm{CO}_{2}$ assimilation of leaves of $Q$ robur seedlings grown in a greenhouse. $\log \left(A_{n}\right)=1.96-0.93 \times \%$ leaf_infected, $r^{2}=0.479, p<0.0001$.

Infection by $E$. alphitoides decreased both $\mathrm{J}_{\max }$, the maximum light-driven electron flux and $\mathrm{Vc}_{\max }$, the apparent maximum carboxylation velocity (Fig. 5). The decrease in $\mathrm{J}_{\max }$ was significant $(F=27.93, p<0.001)$ and was of $20 \%, 25 \%$ and $45 \%$ for leaves with infection indexes 1, 2 and 3, respectively, compared to healthy leaves on the same seedlings, while there was no difference between healthy leaves of healthy or infected seedlings $(t=0.88$, $\mathrm{P}=0.392)$. The decrease in $\mathrm{Vc}_{\max }$ was significant $(\mathrm{F}=50.48, \mathrm{p}<0,001)$ and proportional to the degree of leaf infection, with $25 \%, 40 \%$ et $50 \%$ lower values in leaves with infection indexes of 1,2 and 3 compared to healthy leaves of the same seedlings. As for $J_{\max }$ there was no differences between healthy leaves of control or partly infected seedlings $(t=1.18$, $\mathrm{p}=0.252$ ). To test for an impact of E. alphitoides on nitrogen allocation to biochemical (carboxylation by rubisco) and photochemical processes, we computed the ratios of $\mathrm{Vc}_{\max }$ and of $\mathrm{J}_{\max }$ to nitrogen content. The value of the 2 ratios was significantly different for healthy leaves of partly infected seedling or for healthy leaves of entirely healthy seedling $(t=2.92$, pvalue $=0.009$ for $\mathrm{J}_{\max } / \mathrm{N}$ and $\mathrm{t}=2.88$, pvalue $=0.001$ for $\mathrm{Vc}_{\max } / \mathrm{N}$, Fig. $5 \mathrm{c}$ and $\mathrm{d}$ ). For infected seedlings, the 2 ratios decreased in parallel when infection level increased. The ratio $\mathrm{J}_{\max } / \mathrm{Vc}_{\max }$ increased from 1.7 in healthy leaves to about 2 in the most severely infected leaves $(F=15.61, p<0.001$, Fig. 6$)$ reflecting a stronger impact of infection on carboxylation capacity than on electron transport (Pearson corelation between \% infected leaf area and $\mathrm{Vc}_{\max }, \mathrm{Vc}_{\max } / \mathrm{N}, \mathrm{J}_{\max }$ and $\mathrm{J}_{\max } / \mathrm{N}$ respectively of $-0.781,-0.790,-0.707$ and $-0.770, \mathrm{p}$ $<0.0001)$. 

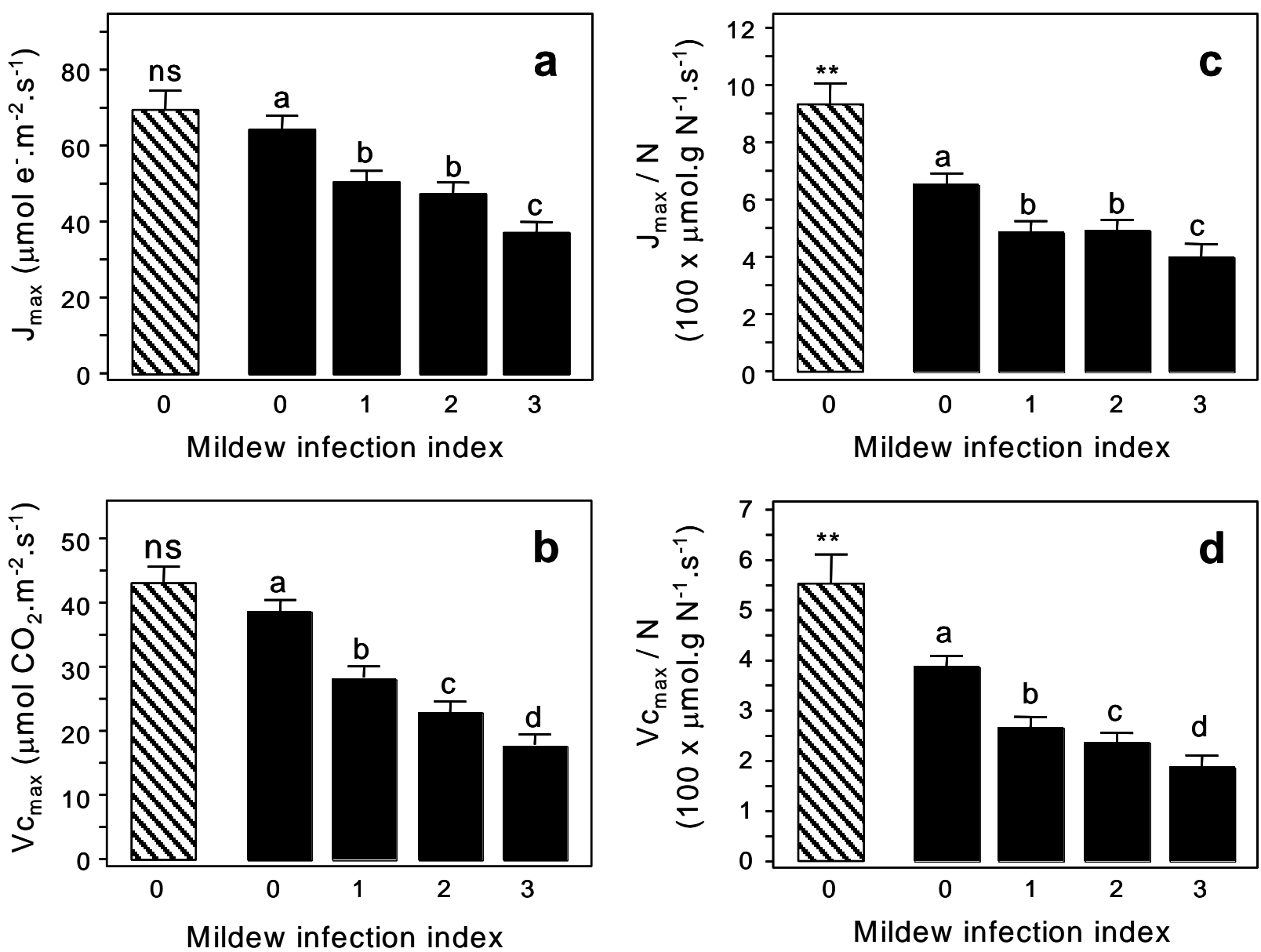

Fig. 5 Impact of oak mildew on photosynthetic capacity of infected leaves. a, Maximum light driven electron flux $\left(\mathrm{J}_{\max }\right) ; \mathrm{b}$, Maximum carboxylation velocity of rubisco $\left(\mathrm{V}_{\mathrm{Cmax}}\right)$; $\mathrm{c}, \mathrm{J}_{\max } / \mathrm{N} ; \mathrm{d}, \mathrm{VC}_{\max } / \mathrm{N}$. leaves on healthy control seddlings. The sign above the bar indicates whether these leaves are significantly different from healthy leaves of partly infected seedlings. W, leaves on seedling partly infected by oak mildew. Bar represent confidence intervals.

\section{Shedding of infected leaves under natural conditions}

The climatic conditions during the experiment were cool and moist with average maximal and minimal daily temperatures of respectively 23.3 and $13.3{ }^{\circ} \mathrm{C}$. The duration before leaf shedding greatly depended on infection level (Fig. 7). While the leaves with infection ratings of 1 or 2 and healthy ones did not differ ( $p=0.89$ and 0.98 , respectively), leaves with infection rating of 3 and 4 showed much shorter life-spans $(p=0.004$ and $p<0.0001$, respectively; see Fig. 7). The median time before shedding was estimated to be 20 days for leaves rated 4 (confidence interval of 10-31 d) while it was larger than the duration of the experiment for all other infection levels.

\section{Discussion}

Our results show that infection with oak powdery mildew had a moderate impact on leaf physiology, slightly reducing stomatal conductance, net $\mathrm{CO}_{2}$ assimilation rates $\left(A_{n}\right)$, and photosynthetic capacity, with a decrease in both maximal light driven electron flux $\left(J_{\max }\right)$ and apparent maximal velocity of RuBP carboxylation $\left(V_{c_{m a x}}\right)$. The decrease of $A_{n}$ in infected leaves was not compensated by an increase in the healthy leaves of the same seedling. However, heavy infection led to a severe decline in leaf life-span. 
The seedlings infected by $E$. alphitoides displayed larger nitrogen content in the leaves than healthy controls. This could be the result of a dilution effect in the faster growing controls, as hypothesized by Bauer et al (2000) for rust-infected spruce needles. Unfortunately, as we did not measure seedling growth, we have no data to support this hypothesis. Oak-mildew infected leaves displayed also a larger carbon content, reflecting the decrease of $\mathrm{N}$, and possibly effects of the fungal biomass.

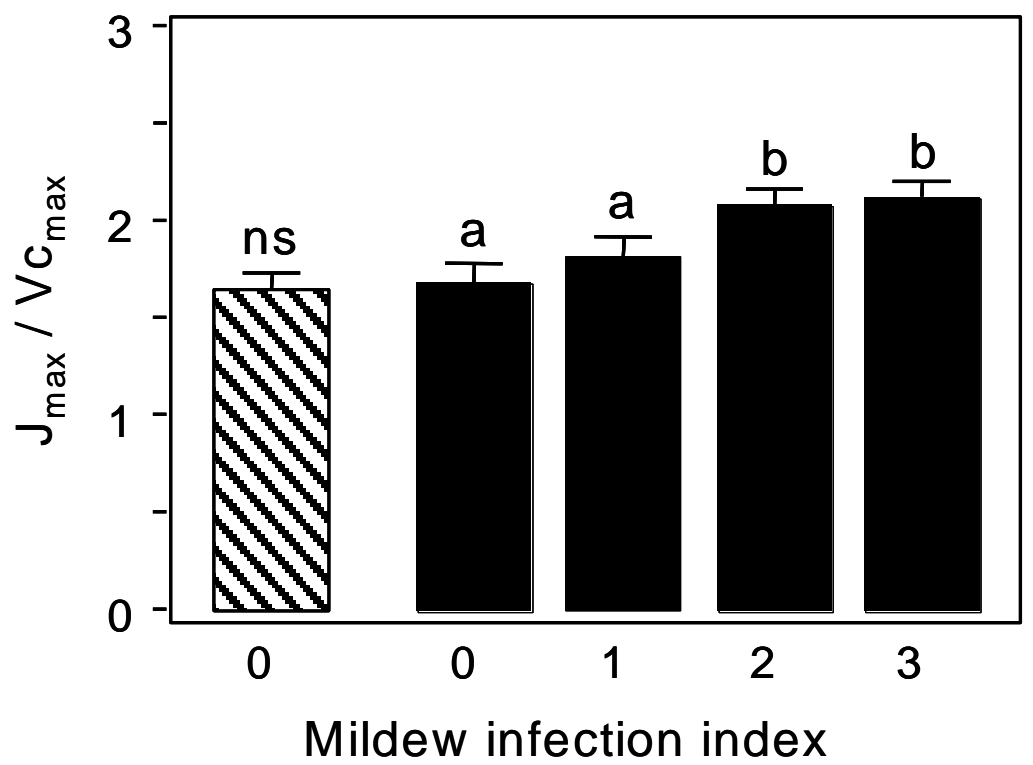

Fig. 6. Impact of oak mildew on the ratio $J_{\max } / V_{C \max }$ in infected leaves , leaves on healthy control seedlings. The sign above the bar indicates whether these leaves were significantly different from healthy leaves of partly infected seedlings. W leaves on seedling partly infected by oak mildew. Bar represent confidence intervals.

Infection by Erysiphe alphitoides only moderately affected transpiration whether at leaf or entire seedling level. The lack of any detectable transpiration at the adaxial surface of the infected leaves while a large transpiration flux was detected at their abaxial surface, where the stomata are located (Experiment 2) indicated that, unlike in observations reported by Hewitt and Ayres (1975), water loss by the epiphytic mildew mycelium on adaxial leaf surfaces was small and undetectable with our techniques. The discrepancy with our results might possibly be explained by the age of the studied leaves, as Hewitt and Ayres (1975) used very young leaves. E. alphitoides decreased the stomatal conductance of infected leaves by about $15-30 \%$ (Experiment 2). Altered behaviour of stomata, with incomplete opening under high light, has already been reported for mildew infected barley leaves (Ayres and Zadoks, 1979). This impact of mildew infection appears to be a very early response, occurring as soon as the epidermal cell are penetrated by the mycelium in susceptible barley cultivars (Prats et al., 2006). A decrease in stomatal conductance linked to infection has also been reported for other leaf pathogens, in particular necrotrophs (Shtienberg, 1992; Roloff et al., 2004; Pinkard and Mohammed, 2006). The smaller stomatal conductance of mildewinfected leaves did not result in a decrease of whole plant transpiration in severely infected saplings (Experiment 1). 


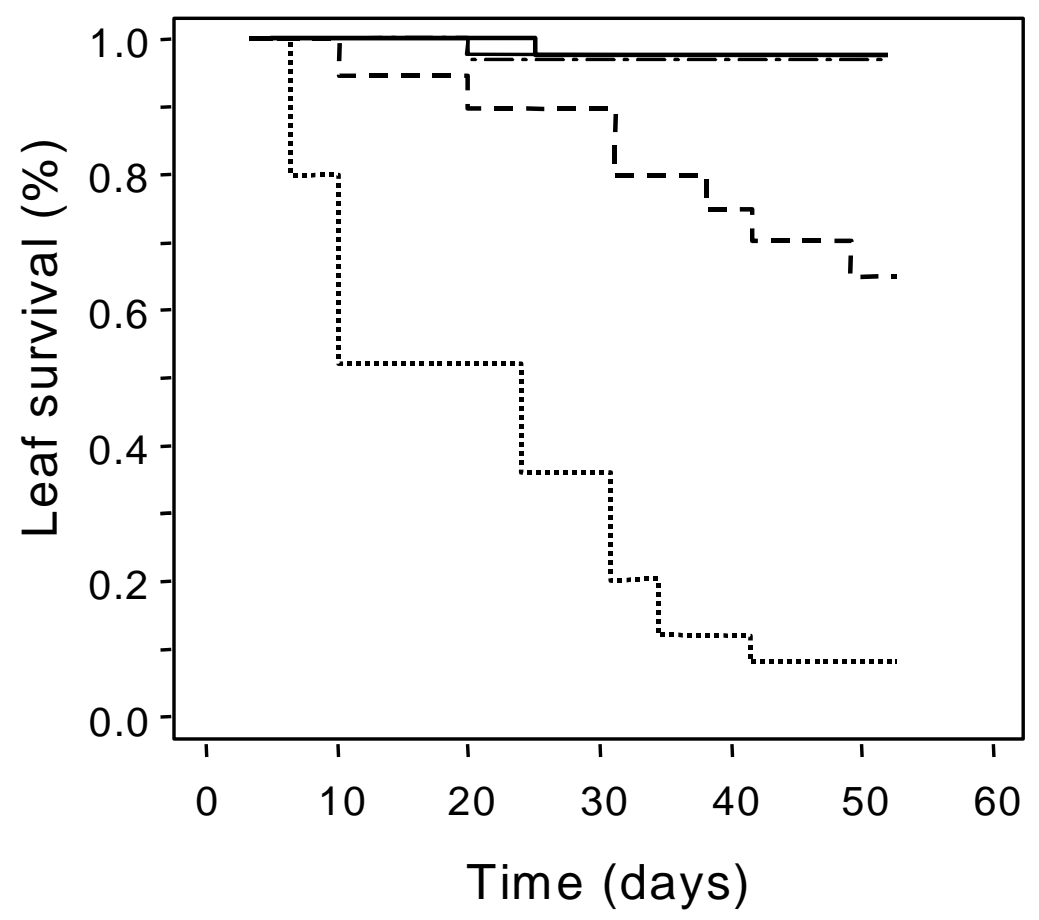

Fig. 7. Time course of the fraction of surviving leaves of $Q$. robur seedlings naturally infected by oak mildew (July to September) in leaf cohorts with different infection index: $0(-), 1(-), 2(-\cdot), 3(--)$ or $4(\cdots .$.$) . Start date$ (Time=0) was 15 July

Infection by $E$. alphitoides had a negative impact on net $\mathrm{CO}_{2}$ assimilation (Experiment 3 ). The decrease of $A_{n}$ as a function of the fraction infected leaf area was exponential as already mentioned for other host / pathogen interactions (Shtienberg, 1992, Roloff et al., 2004). Bastiaan (1991) proposed that the infection-induced reduction in $A_{n}$ could be modelled as follows: $A_{x} / A_{0}=(1-X / 100)^{\beta}$, with $A_{x} / A_{0}$, relative decrease in net $C O_{2}$ assimilation in diseased $\left(A_{x}\right)$ compared to healthy leaves $\left(A_{0}\right)$ and $X$ the percent infected leaf area. This model is commonly used in plant pathology because the coefficient $\beta$ provides an good measure on the pathogen impact on leaf physiology (Lopes \& Berger, 2001; Erickson et al., 2003; Robert et al., 2005; Robert et al., 2006). We could not apply Bastiaan's model to our data as the most severely infected leaves, with the entire leaf area affected by the pathogen, still displayed substantial levels of $A_{n}$, of about $50 \%$ of the value observed in healthy leaves, a result in agreement with values reported by Hewitt and Ayres (1975). This was mainly linked to the absence of necroses in infected leaves, at least under our experimental conditions. Thus, the model of Bastiaan seemed poorly adapted to oak powdery mildew and probably all powdery mildews (Mignucci and Boyer, 1979; Lakso et al., 1982), although it does fit well in the case of other biotrophic pathogens such as rusts (Robert et al., 2005; Robert et al., 2006). Nevertheless, the impact of E. alphitoides on $\mathrm{CO}_{2}$ assimilation was clearly less than what was expected from the fraction infected leaf area. Compensation of reduced photosynthesis in infected leaves by an increased one in healthy leaves did not occur in partially infected seedlings unlike what was reported in other host / pathogen interactions (Mayr et al., 2001).

A small fraction of the decrease in $A_{n}$ was due to an increased respiration $(0.2 \mu \mathrm{mol}$ $\mathrm{CO}_{2} \cdot \mathrm{m}^{-2} \cdot \mathrm{s}^{-1}$ ). Increased respiration is a common occurrence in infected leaves (Hewitt and Ayres, 1975; Sabri et al., 1997; Bauer et al.; 2000). It may be attributed either to an increase in the leaf respiration due to infection or to the respiration of the pathogen itself. The decrease in stomatal conductance was also not likely to have caused the decrease in $A_{n}$ as intercellular $\left[\mathrm{CO}_{2}\right]$ did not appear to be limiting in the strongly infected leaves. By contrast, 
infection by the $E$. alphitoides clearly impacted the photosynthetic capacity of leaves, as they displayed reduced apparent maximal carboxylation rate by Rubisco $\left(\mathrm{Vc}_{\max }\right)$ and maximal light-driven electron transfer rates $\left(\mathrm{J}_{\max }\right)$. An impact of infection on leaf $\mathrm{Vc}_{\max }$ has already been evidenced in other host / pathogen interactions (Niederleitner and Knoppik, 1997; Mayr et al., 2001). The gradual increase of the $\mathrm{J}_{\max } / \mathrm{Vc}_{\max }$ ratio with the percent affected leaf area shows that $E$. alphitoides had a stronger impact on the photosynthetic processes linked to photosynthetic carbon reduction (or to $\mathrm{CO}_{2}$ transfer in the leaf tissues) that to those linked to photochemistry. Also, the larger nitrogen content of infected seedlings did not translate into an increased investment into photosynthesis as $\mathrm{Vc}_{\max } / \mathrm{N}$ and $\mathrm{J}_{\max } / \mathrm{N}$ decreased in healthy leaves of infected seedlings compared to those of healthy seedlings.

Leaf life-span was significantly reduced by infection (Experiment 4) for leaves with infection levels 4 and 3 . Thus, despite the fact that infection had only moderate impacts on transpiration and $\mathrm{CO}_{2}$ assimilation of leaves with an infection level of 3 , such infection by the pathogen does indeed induce some defoliation. Moreover, the studied seedlings grew under the cover of mother trees, i.e., in the shade and the climate during the experiment was cool and wet. The impact of $E$. alphitoides on leaf survival might have been even higher under full sun during a hot summer. This impact of mildew infection on leaf life-span might thus be very important as, even under favourable conditions, only $50 \%$ of the most severely infected leaves were still alive after about 20 days. A severe impact on carbon assimilation and carbon budget may be expected from this decline in leaf life-span, which could result in impaired survivalof the seedlings.

The relatively low impact of $E$. alphitoides on photosynthesis probably explains why the disease has generally moderate consequences for tree health despite heavy infections. The most eignificant impact of the disease was on the life-span of severely infected leaves. Such generalised severe infections on trees occur only occasionally when massive infection occurs during leaf flushing, which is uncommon and happens in particular when the oaks trees refoliates after an insect defoliation (Thomas et al., 2002). In such a case, the impact of oak powdery mildew is expected to be very deleterious. The relationship between leaf infection level and reduction in net photosynthesis that we identified will be very useful for assessing the impact of $E$. alphitoides on whole tree carbon balance.

\section{Acknowledgements}

We want to thank Olivier Caël and Beranger Bertin for their technical assistance

\section{Reference}

Ayres, P.G. \& Zacoks, J.C. (1979). Combined effects of powdery mildew disease and soil water level on the water relations and growth of barley. Physiol. Plant Pathol., 14, 347-361.

Bassanezi, R.B., Amorim, L, Bergamin Filho, A. \& Berger, R.D. (2002). Gas exchange and emission of chlorophyll fluorescence during the monocycle of rust, angular leaf spot and anthracnose on bean leaves as a function of their trophic characteristics. J. of Phytopat., 150, 37-47.

Bastiaan, L. (1991). Ratio between virtual and visual lesion size as a measure to describe reduction in leaf photosynthesis of rice due to leaf blast. Phytopath., 81, 611-615.

Bauer, H., Plattner, K. \& Volgger, W. (2000). Photosynthesis in Norway spruce seedlings infected by the needele rust Chrysomyxa rhododendri. Tree Physiol., 20, 211-216.

Edwards, M.C. \& Ayres, P.G. (1982). Seasonal changes in resistance of Quercus petraea (sessile oak) leaves to Microsphaera alphitoides. Tr. British Mycol. Soc. 78, 569-571.

Erickson, J.E., Stanosz, G.R. \& Kruger, E.L (2003). Photosynthetic consequences of Marssonina leaf spotdiffer between two poplar hybrids. New Phytol. 161, 577-583.

Ethier, G. J. \& Livingston, N. J. (2004). On the need to incorporate sensitivity to CO2 transfer conductance into the Farquhar-vonCaemmerer-Berry photosynthesis model. Plant, Cell Environ. 27, 137-153. 
Farquhar, G.D., Ehleringer, J.R.\& Hubick. K.T. (1989). Carbon isotope discrimination and photosynthesis. Ann. Rev. Plant Physiol. 40, 503-537.

Foex, M.E. (1941). L'invasion des chênes d'europe par le blanc ou oidium. Rev. des eaux et forêts 79 , 338-349.

Holloway, P.J., Maclean, D.J. \& Scott, K.J. (1992). Electron transport in thylakoids isolated from barley leaves infected by the powdery mildew fungus (Erisiphe graminis DC. Ex Merat f..sp. hordei marchal). New Phytol. 120, 145-151.

Hewitt, H.G. \& Ayres, P.G. (1975). Changes in $\mathrm{CO} 2$ and water vapour exchange rates in leaves of Quercus robur infected by Microspheara alphitoides (powdery mildew). Physiol. Plant Path. 7, 127-137.

Hewitt, H.G. \& Ayres, P.G. (1976). Effect of infection by Microsphaera alphitoides (powdery mildew) on carbohydrate levels and translocation in seedlings of Quercus robur. New Phytol. 77, 379-390.

Lakso, A.N., Pratt, C., Pearson, R.C. Pool, R.M. Seem R.C. \& Welser, M. (1982). Photosynthesis, transpiration and water use effeciency of mature grape leaves infected with Uncinula nectar (powdery mildew). Phytopath. 72, 232-236.

Lopes, D.B. \& Berger, R.D (2001). The effect of rust and anthracnose on the photosynthetic competence of diseased bean. leaves. Phytopath. 91, 2121-220.

Marçais, B. \& Bréda, N. (2006). Role of an opportunistic pathogen in the decline of stressed oak trees. J. Ecol. 94, 1214-1223.

Mayr, S., Siller, C. Kriss, M., Oberhuber, W., \& Bauer, H. (2001). Photosynthesis in rust-infected adult Norway spruce in the field. New Phytol. 151, 683-689.

Mignucci, J.S. \& Boyer, J.S. (1979). Inhibition of photosynthesis and transpiration in soybean infected by Microsphaera diffuse. Phytopath. 69, 227-230.

Niederleitner, S. \& Knoppik, D. (1997). Effects of the chery leaf spot pathogen Blumeriella jaapii on gas exchange before and after expression of symptoms on cherry leaves. Physiol. Mol. Plant Path. 51, 145-153.

Pennypacker, B.W., Knievel, D.P., Leath, K.T., Pell, E.J. \& Hill, Jr R.R. (1990). Analysis of photosynthesis in resistant and susceptible Alfalfa clones infected with Verticillium albo-atrum. Phytopath. 80, 1300-1306.

Pinkard, E.A. \& Mohammed, C.L.2006. Photosynthesis of Eucalyptus globulus with Mycosphaerella leaf disease. New Phytol. 170, 119-127.

Prats, E., Gay, A.P., Mur, L.A.J., Thomas, B.J., Carver, T.L.W. (2006). Stomatal lock-open, a consequence of epidermal cell death, follows transient suppression of stomatal opening in barley attacked by Blumeria graminis. J. Ex. Bot. 57, 2211-2226.

Robert, C., Bancal, M.O., Ney, B. \& Lannou, C. (2004). Wheat leaf photosynhesis loss due to leaf rust, with respect to lesion development and leaf nitrogen status. New Phytol. 165, 227-241.

Robert, C., Bancal, M.O. Lannou C. \& Ney, B. (2006). Quantification of the effects of Septoria tritici blotch on wheat leaf gas exchange with respect to lesion age, leaf number, and leaf nitrogen status. J. Exp. Bot. 57, 225-234.

Roloff, I., Scherm, H. \& van lesel, M.W. (2004). Photosynthesis of blueberry leaves as affected by Septoria leaf spot and abiotic leaf damage. Plant Dis. 88, 397-401.

Sabri, N., Dominy, P.J. \& Clarke, D.D. (1997). The relative tolerance of wild and cultivated oats to infection by Erysiphe graminis f.sp. avenae: II. the effects of infection on photosynthesis and respiration. Physiol. and Mol. Plant Path. 50, 321-335.

Shtienberg, D. (1992). Effects of foliar diseases on gas exchange processes: a comparative study. Phytopath. 82, 760-765.

Soutrenon, A. (1998). Une experimentation pluri-annuelle confirme l'impact de l'oïdium sur de jeunes sujets. Les cahiers du DSF, 1-2000 (la santé des forets [France] en 1997), Min. Agri. Peche (DERF), Paris, 93-94.

Thomas, F.M., Blank, R. \& Hartmann, G. (2002). Abiotic and biotic factors and their interactions as causes of oak decline in central Europe. Forest Path. 32, 277-307. 